\title{
Paenibacillus rhizosphaerae sp. nov., isolated from the rhizosphere of Cicer arietinum
}

Correspondence

Encarna Velázquez evp@gugu.usal.es

\author{
Raúl Rivas, ${ }^{1}$ Carmen Gutiérrez, ${ }^{2}$ Adriana Abril, ${ }^{3}$ Pedro F. Mateos, ${ }^{1}$ \\ Eustoquio Martínez-Molina, ${ }^{1}$ Antonio Ventosa ${ }^{2}$ and Encarna Velázquez ${ }^{1}$ \\ Departamento de Microbiología y Genética, Lab. 209, Edificio Departamental de Biología,
Universidad de Salamanca, Campus M. Unamuno, 37007 Salamanca, Spain
${ }^{2}$ Departamento de Microbiología y Parasitología, Facultad de Farmacia, Universidad de Sevilla,
41012 Sevilla, Spain
${ }^{3}$ Cátedra de Microbiología Agrícola, Facultad de Agronomía, Universidad de Córdoba, Argentina
}

Two sporulating bacterial strains designated $\mathrm{CECAP06}{ }^{\top}$ and CECAP16 were isolated from the rhizosphere of the legume Cicer arietinum in Argentina. Almost-complete 16S rRNA gene sequences identified the isolates as a Paenibacillus species. It was most closely related to Paenibacillus cineris LMG $18439^{\top}$ ( $99 \cdot 6 \%$ sequence similarity), Paenibacillus favisporus LMG $20987^{\top}$ (99.4 \% sequence similarity) and Paenibacillus azoreducens DSM $13822^{\top}$ (97.7 \% sequence similarity). The cells of this novel species were motile, sporulating, rod-shaped, Gram-positive and strictly aerobic. The predominant fatty acids were anteiso- $\mathrm{C}_{15: 0,0}, \mathrm{C}_{16: 0}$ and iso- $\mathrm{C}_{16: 0}$. The DNA G $+\mathrm{C}$ content of strains $\mathrm{CECAP06}^{\top}$ and CECAP16 was $51 \cdot 3$ and $50.9 \mathrm{~mol} \%$, respectively. Growth was observed from many carbohydrates, but gas production was not observed from glucose. Catalase and oxidase activities were present. The isolates produced $\beta$-galactosidase and hydrolysed aesculin. Gelatinase, caseinase and urease were not produced. The results of DNA-DNA hybridization showed that the strains from this study constitute a novel species of the genus Paenibacillus, for which the name Paenibacillus rhizosphaerae sp. nov. is proposed. The type strain is $\operatorname{CECAPO6}^{\top}\left(=\mathrm{LMG} 21955^{\top}=\right.$ CECT $\left.5831^{\top}\right)$.
The genus Paenibacillus (Ash et al., 1994) contains several recently described species isolated from plant rhizospheres (Elo et al., 2001; Berge et al., 2002; Daane et al., 2002; von der Weid et al., 2002). Moreover, many species of this genus, including the type species, Paenibacillus polymyxa, have been reported as plant growth-promoting rhizobacteria (Lebuhn et al., 1997; Timmusk \& Wagner, 1999; Timmusk et al., 1999; Helbig, 2001; Beatty \& Jensen, 2002; Maes \& Baeyen, 2003; von der Weid et al., 2003). Nevertheless, many rhizospheric bacterial species present in many soils remain unknown and their identification may be valuable for future studies of plant growth promotion.

In the present report, we describe the chemotaxonomic, morphological, phylogenetic and physiological characteristics of two bacterial strains, CECAP $06^{\mathrm{T}}$ and CECAP16, isolated from the rhizosphere of Cicer arietinum, a legume

Published online ahead of print on 14 January 2005 as DOI 10.1099/ ijs.0.63513-0.

The GenBank/EMBL/DDBJ accession numbers for the 16S rRNA gene sequences of strains CECAP06 $^{\top}$ and CECAP16 are AY751754 and AY751755, respectively.

Micrographs of spores of strain CECAPO ${ }^{\top}$ and a full phylogenetic tree are available as supplementary material in IJSEM Online. cultivated in the Chaco Arido (Argentina). The soils from the Chaco Arido are of alluvial origin (Abril et al., 2005) and have been severely and extensively degraded by overgrazing and deforestation. In the dry winter season, the water balance is negative, resulting in a soil moisture deficit. C. arietinum is a legume that is able to grow in semi-arid soils and which may be an alternative crop in sustainable agriculture and soil recovery. On the basis of the data presented in this work, strains CECAP06 ${ }^{\mathrm{T}}$ and CECAP16 should be placed in a novel species of the genus Paenibacillus, for which the name Paenibacillus rhizosphaerae sp. nov. is proposed.

The isolation was carried out on nutrient agar, as described by Peix et al. (2003), from the rhizospheric soil of two C. arietinum plants, at flowering stage, growing in a soil from the Chaco Arido (Argentina). The colonies of the strains isolated were cream-coloured, opaque, rounded and convex.

The strains were grown on nutrient agar medium for $48 \mathrm{~h}$ to check for motility, using phase-contrast microscopy (Axioskop 2; Zeiss). Cells were gently suspended in sterile water, stained with $0 \cdot 2 \%(\mathrm{w} / \mathrm{v})$ uranyl acetate and examined at $80 \mathrm{kV}$ with a Zeiss EM 209 transmission electron 
microscope (Peix et al., 2003). For scanning electron microscopy, cells and spores were treated as described previously (Valverde et al., 2003) and were observed under a Philips PSEM 500 electron microscope. The Gram behaviour of cells was ascertained by staining (Doetsch, 1981). Cells of CECAP $06^{\mathrm{T}}$ and CECAP16 were Gram-positive, rodshaped, sporulating, motile by means of subpolar flagella and commonly observed as single cells. The spores were subterminal, oval and caused slight swelling of the sporangia (see Supplementary Fig. A available in IJSEM Online). The spore ornamentation resembles that of Paenibacillus favisporus (Velázquez et al., 2004).

Amplification and sequencing of the 16S rRNA gene was performed as described by Rivas et al. (2003a). The sequences obtained were compared with sequences from the GenBank database, using the MegaBLAST program (Ma et al., 2002). Sequences were aligned using CLUSTAL W software (Thompson et al., 1997). The distances were calculated according to the method of Kimura (1980). Phylogenetic trees were inferred using neighbour-joining (Saitou \& Nei, 1987), minimum-evolution (Rzhetsky \& Nei, 1993) and maximum-parsimony methods (Felsenstein, 1983). Bootstrap analysis was based on 1000 resamplings. The MEGA 2.1.0 package (Kumar et al., 2001) was used for all analyses.

The almost-complete (1547 nt) 16S rRNA gene sequences of isolates CECAP $06^{\mathrm{T}}$ and CECAP16 were compared with those held in the GenBank database; we show, here, that the strains from this study are phylogenetically related to species of the genus Paenibacillus. Fig. 1 shows the phylogenetic tree obtained with the neighbour-joining method (taken from Supplementary Fig. B in IJSEM Online). The same results were obtained when maximum-likelihood and maximum-parsimony methods were used (data not shown); Fig. 1 shows bootstrap values only for those branches that were found in all three analyses. The results obtained showed that the novel species is closely related to
Paenibacillus cineris, P. favisporus and Paenibacillus azoreducens. Percentage differences based on pair-wise sequence comparisons were determined using complete $16 \mathrm{~S}$ rRNA gene sequences. The data obtained showed $99 \cdot 6 \%$ similarity with $P$. cineris LMG $18439^{\mathrm{T}}, 99 \cdot 4 \%$ similarity with P. favisporus LMG $20987^{\mathrm{T}}$ and $97 \cdot 7 \%$ similarity with $P$. azoreducens DSM $13822^{\mathrm{T}}$.

DNA-DNA hybridization analyses and determination of DNA $\mathrm{G}+\mathrm{C}$ contents were performed as described by Arahal et al. (2001). DNA-DNA hybridization studies were carried out according to the competition procedure of the membrane method described by Johnson (1994). The hybridization temperature was $51{ }^{\circ} \mathrm{C}$, which is within the limit of validity for the filter method (De Ley \& Tijtgat, 1970), and the percentage of hybridization was calculated according to Johnson (1994). Three independent determinations were carried out for each experiment and the results reported are mean values. The DNA G $+\mathrm{C}$ content of strains CECAP06 $^{\mathrm{T}}$ and CECAP16 was $51 \cdot 3$ and $50.9 \mathrm{~mol} \%$, respectively. These values are similar to those obtained for the phylogenetically closest species of the genus Paenibacillus (Meehan et al., 2001; Logan et al., 2004; Velázquez et al., 2004). The results of DNA-DNA hybridization showed $79 \%$ hybridization between strains CECAP $06^{\mathrm{T}}$ and CECAP16. The values for DNA hybridization of strain CECAP06 $^{\mathrm{T}}$ with $P$. favisporus LMG $20987^{\mathrm{T}}$, P. cineris $\mathrm{LMG}$ $18439^{\mathrm{T}}$ and $P$. azoreducens DSM $13822^{\mathrm{T}}$ were 42,45 and $18 \%$, respectively. The values for DNA hybridization of strain CECAP16 with the aforementioned Paenibacillus species were 46,43 and $<10 \%$, respectively. In terms of DNA-DNA hybridization, the threshold value for the definition of a species is considered to be $70 \%$ (Wayne et al., 1987); consequently, our results indicate that the strains isolated in this study do not belong to any of the known species of Paenibacillus.

The fatty acid composition was analysed by GLC as described by Rivas et al. (2003b) and the results are shown in

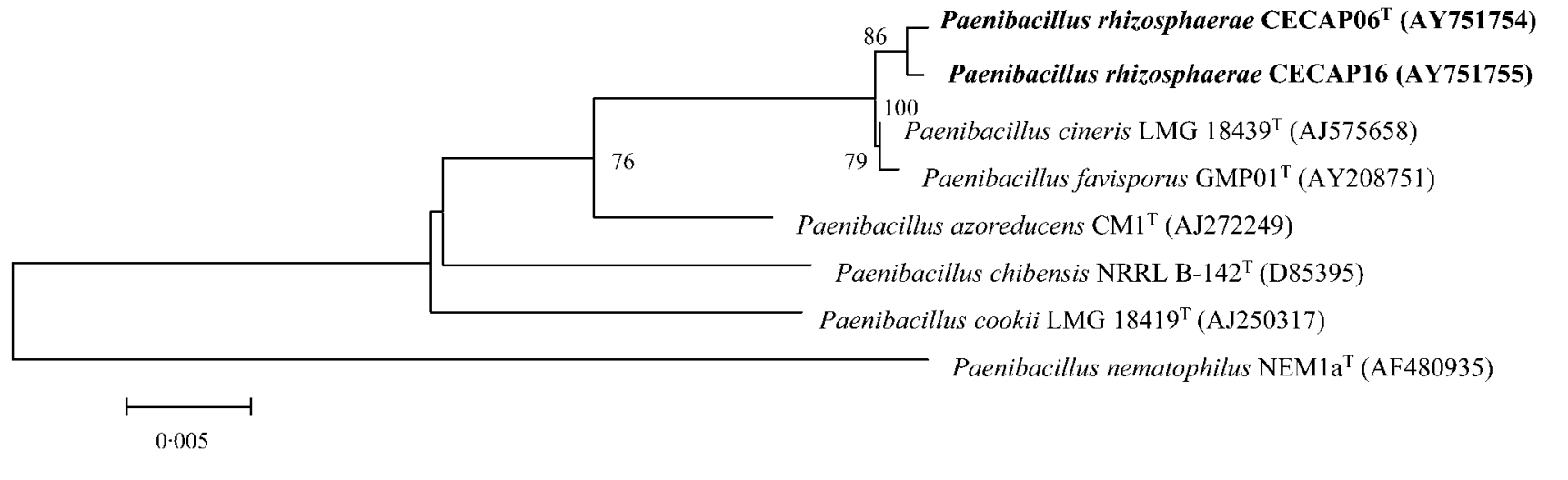

Fig. 1. Phylogenetic analysis of $16 \mathrm{~S}$ rRNA gene sequences from $P$. rhizosphaerae CECAP06 ${ }^{\top}$ and $P$. rhizosphaerae CECAP16 and those of type strains of closely related Paenibacillus species, using the neighbour-joining method. The significance of each branch is indicated by a bootstrap value calculated for 1000 subsets. Only those bootstrap values for the branches that are found with all three analyses used in this study are shown. Bar, 5 nt substitutions per $1000 \mathrm{nt}$. 
Table 1. Cellular fatty acid composition (\%) of strains CECAP06 $^{\top}$ and CECAP16 and phylogenetically related species of the genus Paenibacillus

Data are from Meehan et al. (2001), Velázquez et al. (2004) and this study. Species: 1, P. rhizosphaerae CECAP06 ${ }^{\mathrm{T}}$; 2, P. rhizosphaerae CECAP16; 3, P. cineris LMG $18439^{\mathrm{T}}$; 4, P. favisporus LMG $20987^{\mathrm{T}} ; 5$, P. azoreducens DSM $13822^{\mathrm{T}}$.

\begin{tabular}{|c|c|c|c|c|c|}
\hline Fatty acid & 1 & 2 & 3 & 4 & 5 \\
\hline $\mathrm{C}_{14: 0}$ & $3 \cdot 0$ & $3 \cdot 7$ & $3 \cdot 0$ & $1 \cdot 2$ & $3 \cdot 5$ \\
\hline $\mathrm{C}_{15: 0}$ & $1 \cdot 4$ & $1 \cdot 7$ & $6 \cdot 2$ & $3 \cdot 6$ & $0 \cdot 1$ \\
\hline$C_{16: 0}$ & $16 \cdot 5$ & $18 \cdot 3$ & $18 \cdot 7$ & $8 \cdot 7$ & $22 \cdot 1$ \\
\hline iso- $\mathrm{C}_{14: 0}$ & $1 \cdot 4$ & $1 \cdot 6$ & $1 \cdot 2$ & $0 \cdot 9$ & $0 \cdot 8$ \\
\hline iso- $\mathrm{C}_{15: 0}$ & $8 \cdot 0$ & $7 \cdot 9$ & $6 \cdot 2$ & $6 \cdot 5$ & $5 \cdot 9$ \\
\hline iso- $\mathrm{C}_{16: 0}$ & $10 \cdot 1$ & $10 \cdot 6$ & $9 \cdot 1$ & $11 \cdot 1$ & $8 \cdot 6$ \\
\hline iso- $\mathrm{C}_{17: 0}$ & $4 \cdot 1$ & $3 \cdot 3$ & $3 \cdot 0$ & $3 \cdot 3$ & $5 \cdot 6$ \\
\hline anteiso- $\mathrm{C}_{15: 0}$ & $45 \cdot 5$ & $43 \cdot 2$ & $43 \cdot 2$ & $48 \cdot 8$ & $33 \cdot 9$ \\
\hline anteiso- $\mathrm{C}_{17: 0}$ & $9 \cdot 8$ & $8 \cdot 7$ & $10 \cdot 7$ & $15 \cdot 0$ & $19 \cdot 8$ \\
\hline
\end{tabular}

Table 1 . The predominant fatty acids in the two strains from this study were anteiso- $\mathrm{C}_{15: 0}$ and $\mathrm{C}_{16: 0 \text {. Other fatty }}$ acids detected were iso- $\mathrm{C}_{16: 0}$, iso- $\mathrm{C}_{15: 0}$, anteiso- $\mathrm{C}_{17: 0}$ and small amounts of iso- $\mathrm{C}_{17: 0}, \mathrm{C}_{10: 0}, \mathrm{C}_{14: 0}$ and $\mathrm{C}_{15: 0}$. According to these results, the fatty acid composition of strains CECAP06 $^{\mathrm{T}}$ and CECAP16 is similar to those reported for $P$. azoreducens, P. cineris and P. favisporus (Meehan et al., 2001; Logan et al., 2004; Velázquez et al., 2004).

The phenotypic characterization of the two novel isolates was performed according to the standard methods described by Claus \& Berkeley (1986) and with the API 20E system (bioMérieux) (Logan \& Berkeley, 1984), using strains $P$. favisporus LMG $20987^{\mathrm{T}}$, P. cineris LMG $18439^{\mathrm{T}}$ and P. azoreducens DSM $13822^{\mathrm{T}}$ as references. The API 20NE system was also used to characterize the isolates (according to the manufacturer's instructions). Table 2 shows the distinctive phenotypic features of the novel species as well as those of closely related species belonging to the genus Paenibacillus. Strains $\mathrm{CECAP} 6^{\mathrm{T}}$ and CECAP16 differ only in terms of mannose assimilation. The main difference between the novel species and the closely related species is the inability of the former to grow under anaerobic conditions. This characteristic is quite rare among Paenibacillus species, but the species Paenibacillus chibensis, Paenibacillus validus, Paenibacillus curdlanolyticus and Paenibacillus kobensis are also unable to grow under anaerobic conditions (Shida et al., 1997). Moreover, the novel species differs from $P$. cineris with respect to growth in presence of $5 \%(\mathrm{w} / \mathrm{v}) \mathrm{NaCl}$, from $P$. favisporus with respect to the Voges-Proskauer reaction, growth at $50{ }^{\circ} \mathrm{C}$ and acid production from $\mathrm{L}$-arabinose, and from $P$. azoreducens with respect to the oxidase test, the production of $\mathrm{H}_{2} \mathrm{~S}$, growth in presence of $5 \%(\mathrm{w} / \mathrm{v}) \mathrm{NaCl}$ and acid production from L-arabinose. Therefore, the phenotypic differences between our isolates and phylogenetically related Paenibacillus species are in agreement with the
Table 2. Distinctive phenotypic characteristics of species phylogenetically related to $P$. rhizosphaerae sp. nov.

Data are from Meehan et al. (2001), Logan et al. (2004), Velázquez et al. (2004) and this study. Species: 1, P. azoreducens; 2, P. cineris; 3, P. favisporus; 4, P. rhizosphaerae. Symbols: +, positive; -, negative; V, variable; $\mathrm{W}$, weak; NR, not recorded. All species are catalase-positive and do not use citrate as a sole carbon source, produce indole or produce acid from mannitol and D-xylose.

\begin{tabular}{|lcccc|}
\hline Test & $\mathbf{1}$ & $\mathbf{2}$ & $\mathbf{3}$ & $\mathbf{4}$ \\
\hline Anaerobic growth & + & + & + & - \\
Optimum growth temp. $\left({ }^{\circ} \mathrm{C}\right)$ & 37 & 30 & 37 & 28 \\
Oxidase & - & + & + & + \\
Nitrate reduction & $+{ }^{*}$ & + & + & + \\
Voges-Proskauer test & - & $\mathrm{v}(\mathrm{w})$ & - & + \\
Production of $\mathrm{H}_{2} \mathrm{~S}$ & + & - & - & - \\
Production of: & & & & \\
$\quad$ Gelatinase & + & - & - & - \\
$\quad$ Caseinase & - & $\mathrm{w}$ & - & - \\
Growth at pH $5 \cdot 6$ & + & + & + & $\mathrm{w}$ \\
Growth at $50{ }^{\circ} \mathrm{C}$ & + & + & - & + \\
Growth in presence of $5 \%(\mathrm{w} / \mathrm{v}) \mathrm{NaCl}$ & - & - & $\mathrm{w}$ & + \\
Acid from L-arabinose & - & + & - & + \\
\hline
\end{tabular}

${ }^{\star}$ This result differs from that obtained by Meehan et al. (2001) with the API 20E system.

DNA-DNA hybridization studies that support the placement of these isolates within a novel species.

Therefore, on the basis of these polyphasic taxonomic data, we propose that the isolates from this study should be classified as members of a novel Paenibacillus species, for which the name Paenibacillus rhizosphaerae sp. nov. is proposed.

\section{Description of Paenibacillus rhizosphaerae sp. nov.}

Paenibacillus rhizosphaerae [rhi.zo.sphae'rae. Gr. fem. n. rhiza root; L. fem. n. sphaera -ae (from Gr. fem. n. sphaira -as) ball, any globe, sphere; N.L. gen. fem. n. rhizosphaerae of the rhizosphere].

Cells are rod-shaped, $3 \cdot 0-3 \cdot 1 \times 0 \cdot 9-1 \cdot 0 \mu \mathrm{m}$ and motile by means of peritrichous flagella. Spores are in a subterminal position in the cells and cause slight swelling of the sporangia. Colonies grown on nutrient agar (for $48 \mathrm{~h}$ at $28^{\circ} \mathrm{C}$ ) are circular, convex, cream-coloured, opaque and usually 1-3 $\mathrm{mm}$ in size. Strictly aerobic and Gram-positive. Growth occurs at $10-37^{\circ} \mathrm{C}$ and at $\mathrm{pH} 5-9$. The optimum growth temperature is $28^{\circ} \mathrm{C}$ and the optimum $\mathrm{pH}$ is 7 . Grows without $\mathrm{NaCl}$ and with up to $5 \cdot 0 \%(\mathrm{w} / \mathrm{v}) \mathrm{NaCl}$. Oxidase- and catalase-positive. Gas is not produced from glucose. The following phenotypic and biochemical characteristics were obtained by using the bioMérieux API 20E 
and API 20NE systems. Acid is produced from D-glucose, L-arabinose, sucrose, rhamnose, melibiose, xylose, amygdalin and mannitol. $\mathrm{N}$-Acetylglucosamine, maltose and gentiobiose are used as carbon sources. Mannose is assimilated by strain CECAP16, but not by strain CECAP06 ${ }^{\mathrm{T}}$. Inositol, sorbitol, citrate, propionate, caprate, adipate, malate and phenylacetate are not used as sole sources of carbon. Produces $\beta$-galactosidase but not gelatinase, urease, caseinase, phenylalanine deaminase, lysine decarboxylase, arginine dehydrolase, ornithine decarboxylase, tryptophan deaminase, tyrosinase, indole, dihydroxyacetone or hydrogen sulfide. Produces acetoin (in Voges-Proskauer medium) and reduces nitrate to nitrite. The predominant fatty acids are anteiso- $\mathrm{C}_{15: 0}, \mathrm{C}_{16: 0}$ and iso- $\mathrm{C}_{16: 0}$.

The type strain, CECAP06 $^{\mathrm{T}}\left(=\mathrm{LMG} 21955^{\mathrm{T}}=\mathrm{CECT}\right.$ $5831^{\mathrm{T}}$ ), was isolated from the rhizosphere of the legume Cicer arietinum in Argentina. The $\mathrm{G}+\mathrm{C}$ content of its DNA is $50 \cdot 9 \mathrm{~mol} \%$.

\section{Acknowledgements}

This work was supported by Spanish Government grants to E. M.-M. and E. V. We are grateful to Dr Schumann (Deutsche Sammlung von Mikroorganismen und Zellkulturen, Braunschweig, Germany) for his help with fatty acid methyl ester analysis. We also thank N. Skinner for correction of the English version of the manuscript.

\section{References}

Abril, A. B., Torres, P. A. \& Bucher, E. H. (2005). Nitrogen fixation by phyllosphere in dominant woody plants of the Western Chaco semiarid woodland of Argentina. J Trop Ecol 21, 1-5.

Arahal, D. R., Garcia, M. T., Ludwig, W., Schleifer, K. H. \& Ventosa, A. (2001). Transfer of Halomonas israelensis to the genus Chromohalobacter as Chromohalobacter canadensis comb. nov. and Chromohalobacter israelensis comb. nov. Int J Syst Evol Microbiol 51, 1443-1448.

Ash, C., Priest, F. G. \& Collins, M. D. (1994). Paenibacillus gen. nov. In Validation of the Publication of New Names and New Combinations Previously Effectively Published Outside the IJSB. List no. 51. Int J Syst Bacteriol 44, 852-853.

Beatty, P. H. \& Jensen, S. E. (2002). Paenibacillus polymyxa produces fusaricidin-type antifungal antibiotics active against Leptosphaeria maculans, the causative agent of blackleg disease of canola. Can J Microbiol 48, 159-169.

Berge, O., Guinebretiere, M. H., Achouak, W., Normand, P. \& Heulin, T. (2002). Paenibacillus graminis sp. nov. and Paenibacillus odorifer sp. nov., isolated from plant roots, soil and food. Int J Syst Evol Microbiol 52, 607-616.

Claus, D. \& Berkeley, R. C. W. (1986). Genus Bacillus Cohn 1872, $174^{\mathrm{AL}}$. In Bergey's Manual of Systematic Bacteriology, 1st edn, pp. 1105-1138. Edited by P. H. A. Sneath, N. S. Mair, M. E. Sharpe \& J. G. Holt. Baltimore: Williams \& Wilkins.

Daane, L. L., Harjono, I., Barns, S. M., Launen, L. A., Palleron, N. J. \& Haggblom, M. M. (2002). PAH-degradation by Paenibacillus spp. and description of Paenibacillus naphthalenovorans sp. nov., a naphthalene-degrading bacterium from the rhizosphere of salt marsh plants. Int J Syst Evol Microbiol 52, 131-139.

De Ley, J. \& Tijtgat, R. (1970). Evaluation of membrane filter methods for DNA-DNA hybridization. Antonie van Leeuwenhoek 36, 461-474.
Doetsch, R. N. (1981). Determinative methods of light microscopy. In Manual of Methods for General Bacteriology, pp. 21-33. Edited by P. Gerdhardt, R. G. E. Murray, R. N. Costilow, E. W. Nester, W. A. Wood, N. R. Krieg \& G. B. Phillips. Washington, DC: American Society for Microbiology.

Elo, S., Suominen, I., Kämpfer, P., Juhaoja, J., Salkinoja-Salonen, M. \& Haahtela, K. (2001). Paenibacillus borealis sp. nov., a nitrogenfixing species isolated from spruce forest humus in Finland. Int J Syst Evol Microbiol 51, 535-545.

Felsenstein, J. (1983). Parsimony in systematics: biological and statistical issues. Annu Rev Ecol Syst 14, 313-333.

Helbig, J. (2001). Biological control of Botrytis cinerea Pers. ex Fr. in strawberry by Paenibacillus polymyxa (Isolate 18191). J Phytopathol 149, 265-273.

Johnson, J. L. (1994). Similarity analysis of DNAs. In Methods for General and Molecular Bacteriology, pp. 655-681. Edited by P. Gerhardt, R. G. E. Murray, W. A. Wood \& N. R. Krieg. Washington, DC: American Society for Microbiology.

Kimura, M. (1980). A simple method for estimating evolutionary rates of base substitutions through comparative studies of nucleotide sequences. J Mol Evol 16, 111-120.

Kumar, S., Tamura, K., Jakobsen, I. B. \& Nei, M. (2001). Molecular Evolutionary Genetics Analysis Software. Tempe, AZ: Arizona State University.

Lebuhn, M., Heulin, T. \& Hartmann, A. (1997). Production of auxin and other indolic and phenolic compounds by Paenibacillus polymyxa strains isolated from different proximity to plant roots. FEMS Microbiol Ecol 22, 325-334.

Logan, N. A. \& Berkeley, R. C. W. (1984). Identification of Bacillus strains using the API system. J Gen Microbiol 130, 1871-1882.

Logan, N. A., De Clerck, E., Lebbe, L., Verhelst, A., Goris, J., Forsyth, G., Rodríguez-Díaz, M., Heyndrickx, M. \& De Vos, P. (2004). Paenibacillus cineris sp. nov. and Paenibacillus cookii sp. nov., from Antarctic volcanic soils and a gelatin-processing plant. Int J Syst Evol Microbiol 54, 1071-1076.

Ma, B., Tromp, J. \& Li, M. (2002). PatternHunter: faster and more sensitive homology search. Bioinformatics 18, 440-445.

Maes, M. \& Baeyen, S. (2003). Experiences and perspectives for the use of a Paenibacillus strain as plant protectant. Commun Agric Appl Biol Sci 68, 457-462.

Meehan, C., Bjourson, A. J. \& McMullan, G. (2001). Paenibacillus azoreducens sp. nov., a synthetic azo dye decolorizing bacterium from industrial wastewater. Int J Syst Evol Microbiol 51, 1681-1685.

Peix, A., Rivas, R., Mateos, P. F., Martínez-Molina, E., RodríguezBarrueco, C. \& Velázquez, E. (2003). Pseudomonas rhizosphaerae sp. nov., a novel species that actively solubilizes phosphate in vitro. Int J Syst Evol Microbiol 53, 2067-2072.

Rivas, R., Sánchez, M., Trujillo, M. E., Zurdo-Piñeiro, J. L., Mateos, P. F., Martínez-Molina, E. \& Velázquez, E. (2003a). Xylanimonas cellulosilytica gen. nov., sp. nov., a xylanolytic bacterium isolated from a decayed tree (Ulmus nigra). Int J Syst Evol Microbiol 53, 99-103.

Rivas, R., Willems, A., Subba-Rao, N. S., Mateos, P. F., Dazzo, F. B., Kroppenstedt, R. M., Martínez-Molina, E., Gillis, M. \& Velázquez, E. (2003b). Description of Devosia neptuniae sp. nov. that nodulates and fixes nitrogen in symbiosis with Neptunia natans, an aquatic legume from India. Syst Appl Microbiol 26, 47-53.

Rzhetsky, A. \& Nei, M. (1993). Theoretical foundation of the minimum-evolution method of phylogenetic inference. Mol Biol Evol 10, 1073-1095.

Saitou, N. \& Nei, M. (1987). The neighbor-joining method: a new method for reconstructing phylogenetic trees. Mol Biol Evol 4, 406-425. 
Shida, O., Takagi, H., Kadowaki, K., Nakamura, L. K. \& Komagata, K.

(1997). Emended description of Paenibacillus amylolyticus and description of Paenibacillus illinoisensis sp. nov. and Paenibacillus chibensis. Int J Syst Bacteriol 47, 299-306.

Timmusk, S. \& Wagner, E. G. (1999). The plant-growth-promoting rhizobacterium Paenibacillus polymyxa induces changes in Arabidopsis thaliana gene expression: a possible connection between biotic and abiotic stress responses. Mol Plant Microbe Interact 12, 951-959.

Timmusk, S., Nicander, B., Granhall, U. \& Tillberg, E. (1999). Cytokinin production by Paenibacillus polymyxa. Soil Biol Biochem 31, 1847-1852.

Thompson, J. D., Gibson, T. J., Plewniak, F., Jeanmougin, F. \& Higgins, D. G. (1997). The CLUSTAL_X windows interface: flexible strategies for multiple sequence alignment aided by quality analysis tools. Nucleic Acids Res 25, 4876-4882.

Valverde, A., Velázquez, E., Gutiérrez, C., Cervantes, E., Ventosa, A. \& Igual, J. M. (2003). Herbaspirillum lusitanum sp. nov., a novel nitrogen-fixing bacterium associated with root nodules of Phaseolus vulgaris. Int J Syst Evol Microbiol 53, 1979-1983.

Velázquez, E., de Miguel, T., Poza, M., Rivas, R., Rosselló-Mora, R. \& Villa, T. G. (2004). Paenibacillus favisporus sp. nov., a xylanolytic bacterium isolated from cow faeces. Int J Syst Evol Microbiol 54, 59-64.

von der Weid, I., Frois-Duarte, G., van Elsas, J. D. \& Seldin, L. (2002). Paenibacillus brasilensis sp. nov., a novel nitrogen-fixing species from the maize rhizosphere in Brazil. Int J Syst Evol Microbiol 52, 2147-2153.

von der Weid, I., Alviano, D. S., Santos, A. L., Soares, R. M., Alviano, C. S. \& Seldin, L. (2003). Antimicrobial activity of Paenibacillus peoriae strain NRRL BD-62 against a broad spectrum of phytopathogenic bacteria and fungi. J Appl Microbiol 95, 1143-1151.

Wayne, L. G., Brenner, D. J., Colwell, R. R. \& 9 other authors (1987). International Committee on Systematic Bacteriology. Report of the ad hoc committee on reconciliation of approaches to bacterial systematics. Int J Syst Bacteriol 37, 463-464. 